Journal of

Ecology 2003

91, 1034-1048

\title{
Holocene pollen records from the central Arctic Foothills, northern Alaska: testing the role of substrate in the response of tundra to climate change
}

\author{
W. WYATT OSWALD*†, LINDA B. BRUBAKER*, FENG SHENG HU $\ddagger$ and \\ GEORGE W. KLING $\S$ \\ * College of Forest Resources, University of Washington, Seattle, WA 98195, USA, †Quaternary Research Center, \\ University of Washington, Seattle, WA 98195, USA, \$Departments of Plant Biology and Geology, University of \\ Illinois, Urbana, IL 61801, USA, and §Department of Ecology and Evolutionary Biology, University of Michigan, \\ Ann Arbor, MI 48109, USA
}

\begin{abstract}
Summary
1 To explore the role of edaphic controls in the response of arctic tundra to climate change, we analysed Holocene pollen records from lakes in northern Alaska located on glaciated surfaces with contrasting soil texture, topography and tundra communities. Using indicator taxa, pollen accumulation rates (PARs) and multivariate comparison of fossil and modern pollen assemblages, we reconstructed the vegetational changes at Upper Capsule Lake (Sagavanirktok surface) and Red Green Lake (Itkillik II surface) in response to increased effective moisture between the early and middle Holocene.

2 In the Red Green record, low PARs and the continuous presence of taxa indicative of prostrate-shrub tundra (PST; Equisetum, Polypodiaceae, Thalictrum and Rosaceae) indicate that the vegetation resembled PST throughout the Holocene. During the warm, dry early Holocene (11 300-10 000 cal years BP), PST also occurred on Sagavanirktok surfaces, as evidenced by PST indicators (Bryidae, Polypodiaceae, Equisetum and Rosaceae) in this interval of the Upper Capsule record. However, PARs increased, suggesting increased vegetation cover, PST taxa declined and taxa indicative of dwarfshrub tundra (DST; Rubus chamaemorus and Lycopodium annotinum) increased between 10000 and 7500 cal years BP.

3 We hypothesize that between the early and middle Holocene the fine-textured soils and smooth topography of Sagavanirktok surfaces led to increased soil moisture, greater vegetation cover, permafrost aggradation, anoxic and acidic soil conditions, slower decomposition and the development of a thick organic layer. In contrast, soil moisture remained low on the better-drained Itkillik II surface, and vegetational changes were minor.

4 Landscape-scale substrate variations have an effect on how tundra responds to climate change, suggesting that the response of arctic ecosystems to future variability may be spatially heterogeneous.
\end{abstract}

Key-words: Alaska, North Slope, palaeoecology, palynology, Toolik Lake

Journal of Ecology (2003) 91, 1034-1048

\section{Introduction}

Arctic tundra is spatially heterogeneous, with variations in ecosystem processes and plant community composition occurring at a variety of spatial scales (e.g.

Correspondence: W. Wyatt Oswald, Harvard Forest, Harvard University, PO Box 68, Petersham, MA 01366, USA (tel.
+1 978724 3302; fax +1 978724 3595;

e-mailwoswald@fas.harvard.edu).
Walker 2000). At the scale of the entire circumarctic region, the primary variations in vegetation result from the latitudinal climatic gradient. Growing seasons are shorter and colder at higher latitudes and, as a result, there is a northward decrease in primary productivity, diversity, biomass, plant stature and carbon storage (e.g. Young 1971; Yurtsev 1994; Walker 2000). Tundra ecosystems also vary at smaller spatial scales (1$100 \mathrm{~km}$ ), typically in response to edaphic heterogeneity caused by variations in parent material, eolian deposition 
Holocene pollen records from northern Alaska

(C) 2003 British Ecological Society, Journal of Ecology, 91, 1034-1048 or glacial history (e.g. Elvebakk 1994; Walker 2000). The resulting variations in geomorphology, soil $\mathrm{pH}$ or soil texture within a latitudinal climatic zone can strongly influence ecosystem processes and plant community membership, especially via effects on soil moisture (Walker et al. 1994; Muller et al. 1999).

The effects of both climate and substrate are evident in the vegetational patterns of northern Alaska (Muller et al. 1999; Walker 1999, 2000). Climate is largely responsible for the main north-south vegetational gradient between the Brooks Range and the Arctic Ocean. On the Arctic Coastal Plain, cold, windy conditions and a thin snowpack result in shallow depth to permafrost, poor soil drainage and thus extensive waterlogged areas dominated by wet graminoid tundra (Walker \& Everett 1991; Muller et al. 1999). Further south, in the Arctic Foothills, annual precipitation and summer temperatures are higher than along the coast, and erect dwarf shrubs dominate the vegetation (Walker et al. 1994; Muller et al. 1999). Superimposed on the latitudinal gradient are smaller-scale variations in ecosystems within the coastal plain and foothills vegetational zones, mainly in response to edaphic variability. For example, slightly higher topography in some areas along the coast affords drier soils, resulting in higher abundance of prostrate shrubs (Walker \& Everett 1991; Walker et al. 1998). Similarly, dwarf-shrub tundra, widespread in areas of the Arctic Foothills that were unglaciated during the last part of the Pleistocene, is interrupted by prostrate-shrub tun$\mathrm{dra}$ in areas where late Pleistocene valley glaciers left behind coarse-textured deposits (Walker et al. 1994, 1995). In addition to the difference in shrub stature between the ecosystems of these contrasting substrates, there are also differences in soil $\mathrm{pH}$, nutrient cycling, permafrost depth, soil moisture, carbon storage, plant community diversity and biomass (e.g. Walker et al. 1995; Gough et al. 2000; Munroe \& Bockheim 2001).

Given that ecosystem processes and plant community composition of tundra vegetation in northern Alaska and elsewhere in the Arctic are strongly controlled by climate, we might expect current and future climate changes to have considerable effects on tundra. Many studies have documented recent environmental changes in the northern high-latitudes (e.g. Morison et al. 2000; Serreze et al. 2000), and observed changes in tundra community composition, carbon dynamics and shrub abundance have been attributed to climatic warming (Chapin et al. 1995; Oechel et al. 2000; Sturm et al. 2001). However, despite anticipation that northern ecosystems will continue to change as climate warms in the future (e.g. McGuire et al. 2000), and the growing understanding of edaphic controls on tundra, little attention has been placed on the effect of substrate heterogeneity on the response of tundra to climate change.

In this paper, we use a palaeoecological approach to examine substrate controls on tundra ecosystem response to climate change. By reconstructing the vegetation history of sites that differ in landform and soil characteristics, we examined how substrate influenced ecological changes induced by past climate change. The study was conducted in the central Arctic Foothills of northern Alaska, an ideal setting for this research due to its Pleistocene glacial history and resultant edaphic variability. We analysed pollen records from lakes on contrasting glaciated surfaces, one with flat topography and fine-textured soils, the other with greater relief and coarse-textured soils. The sites are only $11 \mathrm{~km}$ apart, ensuring that they experienced the same climatic changes during the Holocene (i.e. the past $10000{ }^{14} \mathrm{C}$ years or 11500 calibrated ${ }^{14} \mathrm{C}$ years). Specifically, we examine the response of these sites to the onset of cool, moist climatic conditions between the early and middle Holocene, using knowledge of the modern pollen-vegetation relationships for this area (Oswald et al. 2003b) to achieve a detailed interpretation of the vegetational history.

\section{Study area}

The Arctic Foothills is an upland area north of the Brooks Range. This area has cold winters (mean January temperature of $-22^{\circ} \mathrm{C}$ ) and cool summers (mean July temperature of $11^{\circ} \mathrm{C}$ ), with $325 \mathrm{~mm}$ mean annual precipitation, most of which falls during summer (Zhang et al. 1996). Permafrost is continuous throughout the area (Hamilton 1978).

The central Arctic Foothills have been glaciated repeatedly, and evidence of three major Pleistocene glacial advances exists in the study area (Fig. 1 and Oswald et al. 2003b). Landscapes of Sagavanirktok age (> 125000 years BP) have been subjected to long periods of mass wasting, weathering and loess deposition and, as a result, have gently rolling topography and fine-textured soils. These surfaces are dominated by dwarf-shrub tundra (DST) communities, which have nearly continuous vegetation cover, a relatively tall plant canopy, and feature dwarf shrubs (e.g. Betula nana), the tussock-forming sedge Eriophorum vaginatum and a thick layer of Sphagnum mosses (Walker et al. 1994). In contrast, areas glaciated by the Itkillik II ice advance (24 000-11 500 years BP) have irregular topography and coarser, better-drained soils (Hamilton 1978, 1994; Bockheim et al. 1998; Munroe \& Bockheim 2001). These surfaces are dominated by prostrate-shrub tundra (PST), which has a sparser, shorter canopy and features non-tussock sedges, prostrate shrubs and non-Sphagnum mosses (Walker et al. 1994, 2001).

Oswald et al. (2003b) showed that lakes on Itkillik II and Sagavanirktok surfaces could be differentiated based on their modern pollen assemblages, and that the modern pollen spectra of Itkillik II and Sagavanirktok samples realistically reflected their PST and DST communities, respectively. Sagavanirktok samples therefore have relatively high pollen or spore percentages of many taxa that are either prevalent in or restricted to DST, including Rubus chamaemorus, Sphagnum, Ericales, Lycopodium annotinum, Betula and Polygonum bistorta, whereas Itkillik II samples have lower percentages 

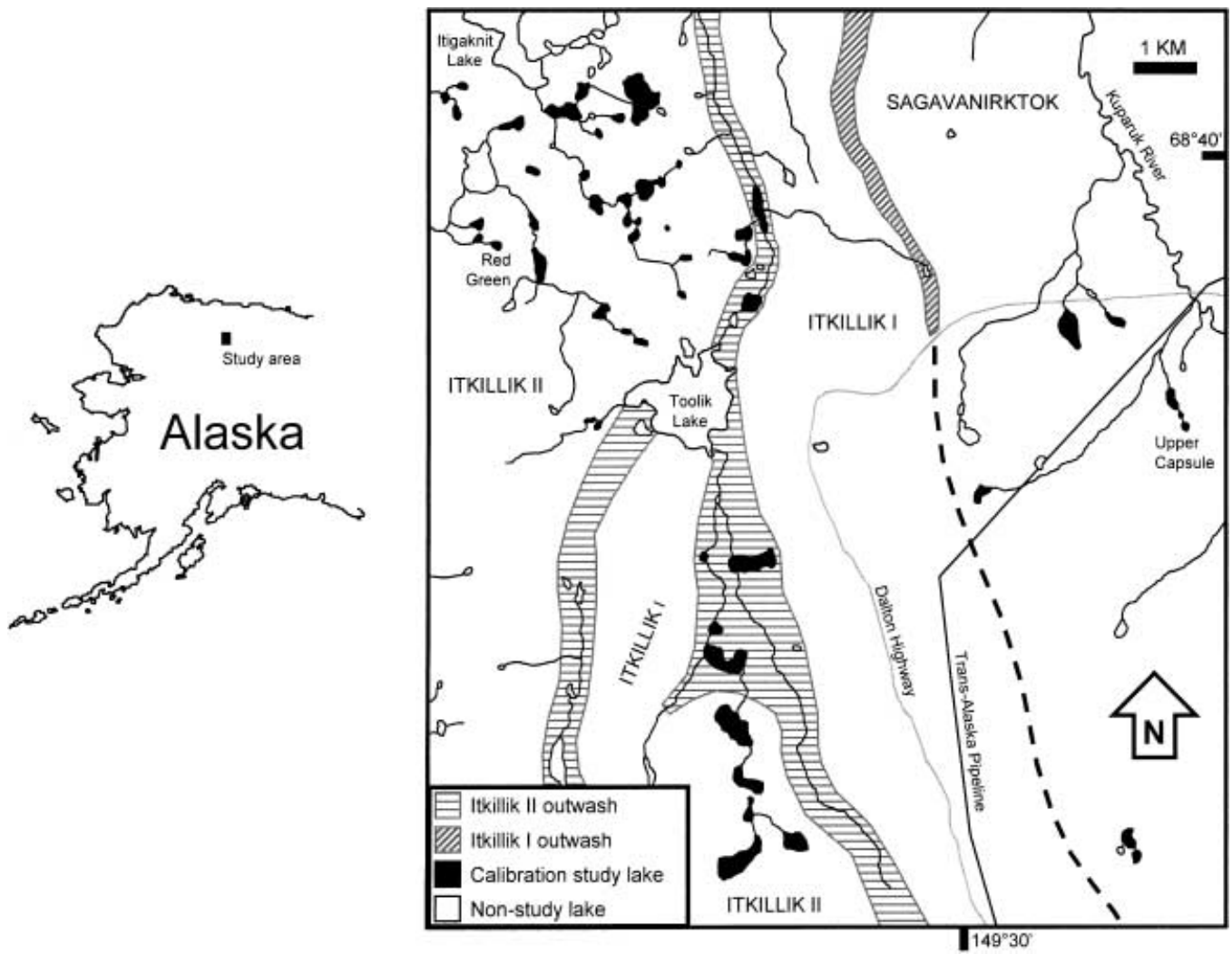

Fig. 1 Map of the study area with locations of Red Green Lake and Upper Capsule Lake. Glacial geology is redrawn from Hamilton (1978) and Walker et al. (1995). The Itkillik I outwash and dashed line define the boundary between the Sagavanirktok and Itkillik I surfaces. Lakes drawn in black were sampled for pollen-vegetation calibration study (Oswald et al. 2003b). Four additional pollen-vegetation calibration lakes are located as far as $19 \mathrm{~km}$ north-east of this study area (beyond map boundary).

of the DST indicator taxa, and higher percentages of taxa associated with PST, including Equisetum, Thalictrum, Rosaceae and Polypodiaceae (Table 1).

We selected two study sites with plant communities representing these vegetation types. Red Green Lake $\left(68^{\circ} 39.2^{\prime} \mathrm{N}, 149^{\circ} 40.9^{\prime} \mathrm{W}\right)$ is located on the Itkillik II surface about $3 \mathrm{~km}$ north-west of Toolik Lake, the

Table 1 Taxa indicative of the vegetation of the Itkillik II surface (PST) and the Sagavanirktok surface (DST) according to modern pollen-vegetation calibration study (Oswald et al. 2003b). Encalypta is considered a PST indicator following Brubaker et al. (1998)

\begin{tabular}{ll}
\hline DST indicators & PST indicators \\
\hline Rubus chamaemorus & Equisetum \\
Sphagnum & Polypodiaceae \\
Ericales & Thalictrum \\
Poaceae & Rosaceae \\
Brassicaceae & Encalypta \\
Lycopodium annotinum & Bryidae (excluding Encalypta) \\
Saxifragaceae & Selaginella rupestris \\
Asteraceae & \\
$\quad$ (excluding Artemisia) & \\
Lycopodiaceae (excluding & \\
L. annotinum and H. selago) & \\
Betula & \\
Polygonum bistorta & \\
\hline
\end{tabular}

location of the Arctic Long-Term Ecological Research site (Fig. 1). The $c$. 2-ha lake (3.2 m maximum depth) is located in a $c$. 50-ha watershed dominated by PST. It has a single outlet stream that flows west into the Itkillik River. Upper Capsule Lake (68³7.8’ N, 149²4.6 $\mathrm{N})$ sits on the Sagavanirktok surface about $7 \mathrm{~km}$ east of Toolik Lake. It is $c .1$ ha in area (5.7 m maximum depth), and is located in a $c$. 350-ha watershed dominated by DST and shrub communities. A single outlet stream flows northward through two other small lakes before reaching the Kuparuk River.

\section{Holocene climate history}

Knowledge of the Holocene climate history of northern Alaska is based on various types of palaeoclimatic evidence, including fossil pollen data, plant and insect macrofossils, lake-sediment geochemistry from sites in northern and interior Alaska, lake-level reconstructions from interior Alaska and General Circulation Model (GCM) predictions. Our understanding of the mechaisms and patterns of Holocene climate change remains uncertain, but some general aspects are agreed upon. For example, climate became warmer and wetter during the late glacial period (15 000-11 500 cal years BP) as summer insolation increased, the Bering land bridge began to flood, and the influence of the Laurentide ice
Ecological Society, Journal of Ecology, 91, 1034-1048 
1037

Holocene pollen records from northern Alaska
(C) 2003 British Ecological Society, Journal of Ecology, 91, 1034-1048 sheet on large-scale circulation patterns began to diminish (Bartlein et al. 1992). Lake levels in interior Alaska rose rapidly during this interval (Abbott et al. 2000; Edwards et al. 2001) and shrub Betula expanded throughout northern Alaska (e.g. Anderson \& Brubaker 1994).

By the early Holocene (11 500-8500 cal years BP), the Laurentide ice sheet exerted little influence on circulation patterns in Alaska and summer insolation reached a relative maximum (Bartlein et al. 1992). Lake-level data from interior Alaska indicate that precipitation was probably still lower than present, whereas temperatures were relatively warm (Abbott et al. 2000; Edwards et al. 2001). In northern Alaska, several types of palaeoclimatic evidence suggest that summer temperatures may have even been warmer than present. For example, few glaciers in the central Brooks Range persisted during this interval (Ellis \& Calkin 1979), and early Holocene fluvial deposits from the northern Arctic Foothills contain insects indicative of well-drained substrates and summer temperatures 2-3 ${ }^{\circ} \mathrm{C}$ warmer than present (Nelson \& Carter 1987). Furthermore, Populus wood dated to this interval occurs at sites beyond its modern range (Detterman 1970; Hopkins et al. 1981; Nelson \& Carter 1987), and Populus pollen occurs in lake sediments at sites north of the modern limit of Populus (Oswald et al. 1999; Mann et al. 2002b). The early Holocene expansion of Populus is not fully understood (e.g. Bartlein et al. 1995; Hu et al. 1998), but the positive correlation between Populus balsamifera radial growth and summer temperature (Edwards \& Dunwiddie 1985) indicates that it may have been a response to warm conditions. Alternatively, recent analyses of Populus macrofossils and fluvial deposits in northern Alaska suggest that the northward expansion of Populus may have been associated with periods of stream aggradation during which Populus established on newly deposited gravel bars (Mann et al. 2002b).

Summer insolation decreased after 8500 cal years BP (Bartlein et al. 1992), and effective moisture increased in response to either cooler temperatures, increased precipitation or both ( $\mathrm{Hu}$ et al. 1998; Anderson et al. 2001; Edwards et al. 2001). Between 8500 and $6500 \mathrm{cal}$ years BP, the increase in effective moisture crossed a threshold that permitted the expansion of Alnus throughout Alaska (e.g. Anderson \& Brubaker 1994; Brubaker et al. 2001), including the region north of the Brooks Range (e.g. Eisner 1991; Oswald et al. 1999). The boundary conditions that control large-scale climatic variability reach their modern levels after 6500 cal years BP (Bartlein et al. 1992), and pollen and lakelevel records from interior and northern Alaska give no indication of major climatic variations during this interval (e.g. Anderson \& Brubaker 1994; Abbott et al. 2000). However, century-scale climatic variations are indicated by other evidence, including Brooks Range glacial advances, beach ridge dynamics along the north-west coast, dune activity in the Kobuk Valley and lake-sediment geochemistry (e.g. Ellis \& Calkin 1984; Calkin 1988; Mason \& Jordan 1993; Anderson et al. 2001; Mann et al. 2002a). There is particularly strong evidence for warm, dry conditions during the Medieval Warm Period, c. 1100-600 cal years BP, and cool, wet conditions during the Little Ice Age, $c$. 600 200 cal years BP (Hu et al. 2001; Mann et al. 2002a).

\section{Methods}

Red Green Lake was cored through $2 \mathrm{~m}$ of ice in May 1997, and Upper Capsule Lake was cored from a raft in July 1997. Uppermost sediments, including an undisturbed mud-water interface, were collected using a piston surface-sediment sampler and extruded vertically in 0.5-cm segments. Lower sediments were retrieved using a $4.5-\mathrm{cm}$ diameter square-rod piston sampler (Wright et al. 1984) and extruded in 1-m drive lengths.

Sediment subsamples $\left(1 \mathrm{~cm}^{3}\right)$ were dried at $90{ }^{\circ} \mathrm{C}$ and ashed at $550{ }^{\circ} \mathrm{C}$ to calculate loss-on-ignition (LOI). Subsamples of 2 or $3 \mathrm{~cm}^{3}$ were prepared for pollen analysis following standard procedures for organic-poor sediments (Cwynar et al. 1979). Tablets containing Lycopodium clavatum spores were added to the subsamples to allow estimation of pollen concentrations and pollen accumulation rates (Stockmarr 1971). Pollen residues were stained with safranin, mounted in silicone oil and examined microscopically using 40 and $100 \times$ objectives ( $12 \times$ eyepieces). Non-Sphagnum moss (Bryidae) spores were classified according to Brubaker et al. (1998) and ascomycete spores were identified following van Geel (1972, 1978; van Geel et al. 1982). At least 300 pollen grains of terrestrial plant taxa were counted for each sample, and all pollen and spore abundances are expressed as a percentage of the sum of identified and unidentified terrestrial pollen grains.

To interpret the fossil pollen assemblages, we relied upon previous studies of the modern relationships between pollen data and patterns of different tundra communities in northern Alaska (Oswald et al. 2003a), in particular the landscape-scale patterns of PST and DST on the Itkillik II and Sagavanirktok surfaces (Oswald et al. 2003b). Our interpretation involved several approaches, including analysis of indicator taxa, multivariate comparison of pollen assemblages, and calculation of pollen accumulation rates (PARs). First, we examined patterns of individual pollen and spore types that are known to be indicative of modern plant communities or specific environmental conditions (indicator taxa, e.g. Cwynar 1982). Taxa were classified as indicators (Table 1) based on their association with DST or PST in a modern pollen-calibration study for this area (Oswald et al. 2003b), as well as other calibration studies for northern Alaska (Brubaker et al. 1998; Oswald et al. 2003a). Secondly, we compared entire pollen assemblages between fossil and modern samples using a multivariate dissimilarity metric (modern analogue method, e.g. Overpeck et al. 1985). For each record, we calculated the Canberra metric distance (CMD) between each fossil pollen assemblage and each of the modern pollen assemblages from the Itkillik II and 
1038

W. Wyatt Oswald et al.
Sagavanirktok surfaces. CMD is a dissimilarity metric in which the distance between multivariate samples is strongly influenced by minor taxa, and it was shown to be more effective than the widely applied squared chord distance for distinguishing between the Itkillik II and Sagavanirktok modern pollen assemblages (Oswald et al. 2003b). As an index of the similarity of each fossil sample to modern PST and DST plant communities, we calculated its average CMD to the Itkillik II $(n=44)$ and Sagavanirktok $(n=12)$ modern samples. Analyses of the modern pollen data set identified a CMD of 13 as the 'critical value' for distinguishing between like and unlike plant communities. Lastly, to approximate the overall vegetation cover of past plant communities, fossil PARs (number of grains $\mathrm{cm}^{-2}$ year $^{-1}$ ) were compared with modern PARs from northern Alaska. The link between PARs and tundra vegetation cover has been disputed (e.g. Guthrie 1985), but Oswald et al. (2003a) found that patterns of vegetation cover were broadly reflected by modern PARs in the Arctic Foothills.

\section{Results}

\section{CORE STRATIGRAPHY AND CHRONOLOGY}

The Red Green Lake sediment core (Fig. 2) consists of coarse sand $(285-239 \mathrm{~cm})$ overlain by inorganic, irregularly banded, grey-brown silt (239-209 cm) and dark organic silt $(209-0 \mathrm{~cm})$. Mollusc shells are abundant between 200 and $160 \mathrm{~cm}$. LOI is low $(<10 \%)$ below 200 $\mathrm{cm}$, and higher (30-50\%) above $200 \mathrm{~cm}$. Pollen was not analysed below $240 \mathrm{~cm}$ due to very low pollen concentrations. The base of the Upper Capsule Lake core is inorganic silt (328-327 cm) overlain by peaty organic sediment (327$310 \mathrm{~cm}$ ) with high LOI $(50-60 \%)$. Between 310 and $273 \mathrm{~cm}$, the sediment is grey-brown silt with diffuse bands, and the upper $273 \mathrm{~cm}$ of the core is dark organic silt. LOI values decrease above $310 \mathrm{~cm}$ (12-32\%).

For both records, dating control is provided by accelerator mass spectrometry (AMS) ${ }^{14} \mathrm{C}$ analyses of plant fragments sieved (> $500 \mu \mathrm{m})$ from the sediment (Fig. 2, Table 2). Seven ages were obtained for the Red Green core, one of which $(202-203 \mathrm{~cm})$ is the average of three ${ }^{14} \mathrm{C}$ dates for different plant materials from the same depth (Oswald 2002). The dates were converted to calibrated ages with the CALIB 4.1 program (Stuiver \& Reimer 1993). The age of the $16-21 \mathrm{~cm}$ sample was rejected because it was anomalously old relative to the age-depth relationship for the other dates from the core (Fig. 2). The age-depth model used to calculate PARs and to assign sample ages is based on linear interpolation between the six remaining calibrated ${ }^{14} \mathrm{C}$ ages.

We obtained nine ages for the Upper Capsule record, two of which (155-157 and 310-311 cm) are the average age of multiple ${ }^{14} \mathrm{C}$ dates for different plant materials from the same depth (Oswald 2002). These dates
(C) 2003 British Ecological Society, Journal of Ecology, 91, 1034-1048

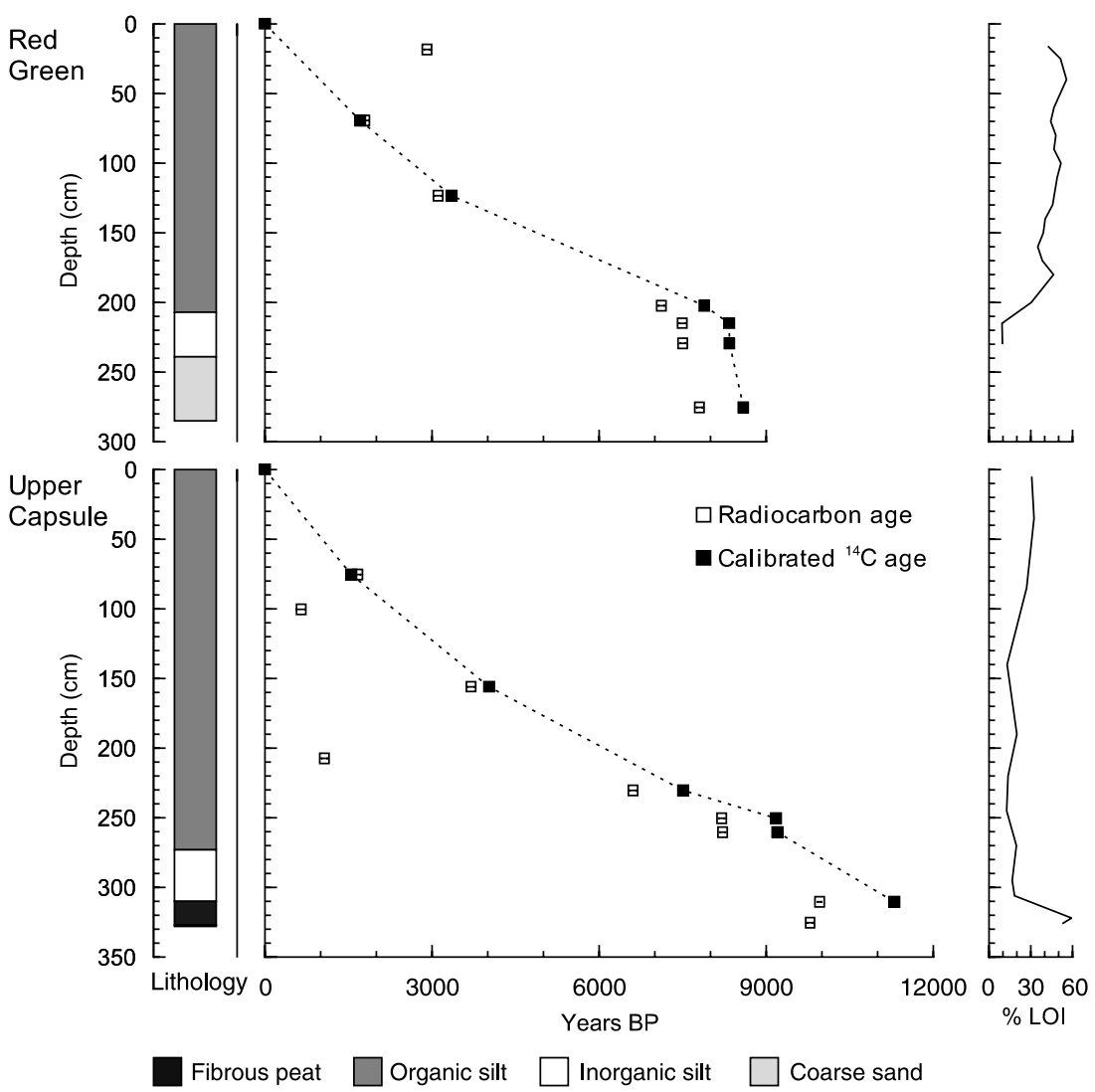

Fig. 2 Lithology, chronology and percentage weight loss-on-ignition (\% LOI) for sediment cores from Red Green Lake and Upper Capsule Lake. The age-depth plots show radiocarbon ages (with $\pm 1 \mathrm{SE}$ indicated by horizontal line within each symbol) and calibrated ${ }^{14} \mathrm{C}$ ages for those dates included in the age-depth model. 
Table 2 Radiocarbon dates from Red Green and Upper Capsule Lakes. Calibrated ages in bold were used in age-depth model. See Oswald (2002) for discussion of average ages from multiple dates

\begin{tabular}{|c|c|c|c|c|c|}
\hline Depth $(\mathrm{cm})$ & ${ }^{14} \mathrm{C}$ years $\mathrm{BP}$ & $\begin{array}{l}\text { CAMS } \\
\text { number }\end{array}$ & Material & $\begin{array}{l}\text { Mass } \\
(\mathrm{mg} \mathrm{C})\end{array}$ & $+1 \mathrm{SE}\left[\right.$ Calibrated ${ }^{14} \mathrm{C}$ age(s) BP] $-1 \mathrm{SE}$ \\
\hline \multicolumn{6}{|l|}{ Red Green } \\
\hline $16-21$ & $2910 \pm 100$ & 69507 & Plant and insect fragments & 0.06 & $3236[3061,3046,3037,3007,3003] 2886$ \\
\hline $69-70$ & $1790 \pm 50$ & 54625 & Terrestrial moss fragments & 0.16 & $1816[\mathbf{1 7 1 0}] 1627$ \\
\hline $123-124$ & $3110 \pm 60$ & 54626 & Moss fragments and stems & 0.47 & $3382[\mathbf{3 3 5 0}] 3265$ \\
\hline $202-203$ & $7116 \pm 73$ & - & Average age for three dates* & - & $8001[7940, \mathbf{7 8 8 5}, 7882] 7859$ \\
\hline $214-216$ & $7490 \pm 100$ & 64011 & Moss and semi-woody pieces & 0.09 & $8389[\mathbf{8 3 3 5}] 8180$ \\
\hline $229-230$ & $7500 \pm 70$ & 54627 & Wood and moss fragments & 0.17 & $8385[\mathbf{8 3 4 1}] 8195$ \\
\hline $275-276$ & $7800 \pm 140$ & 64012 & Semi-woody fragment & 0.06 & $8928[\mathbf{8 5 9 0}] 8413$ \\
\hline \multicolumn{6}{|c|}{ Upper Capsule } \\
\hline $75-76$ & $1670 \pm 50$ & 66740 & Moss fragments & 1.37 & $1687[\mathbf{1 5 5 3}] 1524$ \\
\hline $100-101$ & $650 \pm 80$ & 54634 & Betula and other leaf fragments & 0.08 & $668[649,578,572] 549$ \\
\hline $155-157$ & $3705 \pm 67$ & - & Average age for two of three datest & - & $4148[4081, \mathbf{4 0 3 0}, 3993] 3929$ \\
\hline $207-208$ & $1070 \pm 50$ & 64013 & Terrestrial moss fragments & 0.51 & $1051[966] 932$ \\
\hline $230-231$ & $6610 \pm 60$ & 54635 & Woody and semi-woody pieces & 0.41 & $7569[7551,7542, \mathbf{7 5 0 5}, 7499,7484] 7431$ \\
\hline $250-251$ & $8200 \pm 50$ & 66744 & Terrestrial moss fragments & 1.08 & $9268[9238,9220,9187, \mathbf{9 1 7 8}, 9130,9095,9093] 9030$ \\
\hline $260-261$ & $8220 \pm 50$ & 54636 & $\begin{array}{l}\text { Leaf, terrestrial moss, and } \\
\text { graminoid pieces }\end{array}$ & 0.47 & $9395[9248,9216,9208, \mathbf{9 1 9 8}, 9192,9172,9133] 9033$ \\
\hline $310-311$ & $9957 \pm 32$ & - & Average age for six of seven dates§ & - & $11545[11333,11321,11298,11270,11262] 11257$ \\
\hline $325-326$ & $9790 \pm 50$ & 54637 & Plant and woody fragments & 0.71 & $11226\left[\begin{array}{ll}11 & 196\end{array}\right] 11172$ \\
\hline
\end{tabular}

*Average of CAMS 66737,66738 and 66739.

†Average of CAMS 66741 and $66743 ; 66742$ not used.

\$Second sample from this level (CAMS 66745 ) not used.

§Average of CAMS $66734,66735,66736,66746,66748$ and $66749 ; 66747$ not used.

were also converted to calibrated ages using CALIB. We reject the dates for 100-101 and 207-208 cm, which are younger than would be expected based on the age-depth relationship for the other dates (Fig. 2). The ages of the lowest samples (310-311 and 325-326 cm) are statistically the same, indicating that the organic peat at the base of the core was deposited rapidly, and thus the age from $325 \mathrm{~cm}$ to $326 \mathrm{~cm}$ is not included in the age-depth model. PAR calculations and age assignments are based on linear interpolation between the six remaining calibrated ${ }^{14} \mathrm{C}$ ages.

EARLY HOLOCENE (ZONE 1: $11300-10000 \mathrm{CAL}$ YEARS BP)

The records from the two lakes begin at different times, and only the Upper Capsule record covers the early Holocene interval (Fig. 3). The Sagavanirktok surface was not glaciated during the late Pleistocene (Hamilton 1978), but the Upper Capsule basin appears to have been dry during the Itkillik II glaciation, perhaps due to low precipitation. The peaty basal sediments of the Upper Capsule core suggest that the basin first contained a bog or wetland, but the statistically identical ${ }^{14} \mathrm{C}$ dates at the bottom and top of the peat indicate that the conditions favouring the accumulation of organic sediments were short-lived. The change from peat to silty sediment indicates that the lake began to fill

(C) 2003 British Ecological Society, Journal of Ecology, 91, 1034-1048 around $11300 \mathrm{cal}$ years BP. In contrast, the lack of record from Red Green Lake (Fig. 4) during this part of the Holocene may indicate that Itkillik II landscapes were unstable due to recent glacial retreat, the continued presence of stagnant ice and low vegetation cover.

Zone 1 pollen assemblages for Upper Capsule (UC-1, Fig. 3) are dominated by Cyperaceae (c. 50\%), Betula (c. 35\%), Ericales (5-20\%), Salix (c. 5\%) and Sphagnum (c. $5 \%$ ), with minor taxa indicative of the modern vegetation of the Itkillik II surface, including Thalictrum, Polypodiaceae, Equisetum, Encalypta, Bryidae and Selaginella rupestris (Oswald et al. 2003b). These assemblages reflect tundra dominated by Cyperaceae species and prostrate shrubs (Salix and Ericaceae), probably not unlike modern PST. Indeed, comparison of UC-1 assemblages with modern pollen spectra (Fig. 5) suggests that the early Holocene vegetation near Upper Capsule was compositionally similar to the current tundra of the Itkillik II surface (CMD < 13). Taxa indicative of mesic tundra (Betula and Sphagnum) are present in UC-1, but the similarity of their percentages with modern pollen spectra of the Itkillik II surface suggests that they were uncommon. For example, Betula and Sphagnum percentages in UC-1 are comparable with those in modern lake sediments from the Itkillik II surface (c. $35 \%$ and $2 \%$, respectively), where Betula nana and Sphagnum species are rare at present (Walker et al. 1994). PAR values in UC1 (c. 2000 grains $\mathrm{cm}^{-2}$ year $^{-1}$ ) are higher than modern PARs for PST (c. 300 grains cm ${ }^{-2}$ year $^{-1}$; Oswald et al. 2003a), perhaps reflecting somewhat higher vegetation cover than that of the Itkillik II surface at present. Alternatively, the difference in PARs may reflect greater allochthonous input for Upper Capsule than Red Green, which is likely given its larger watershed. 


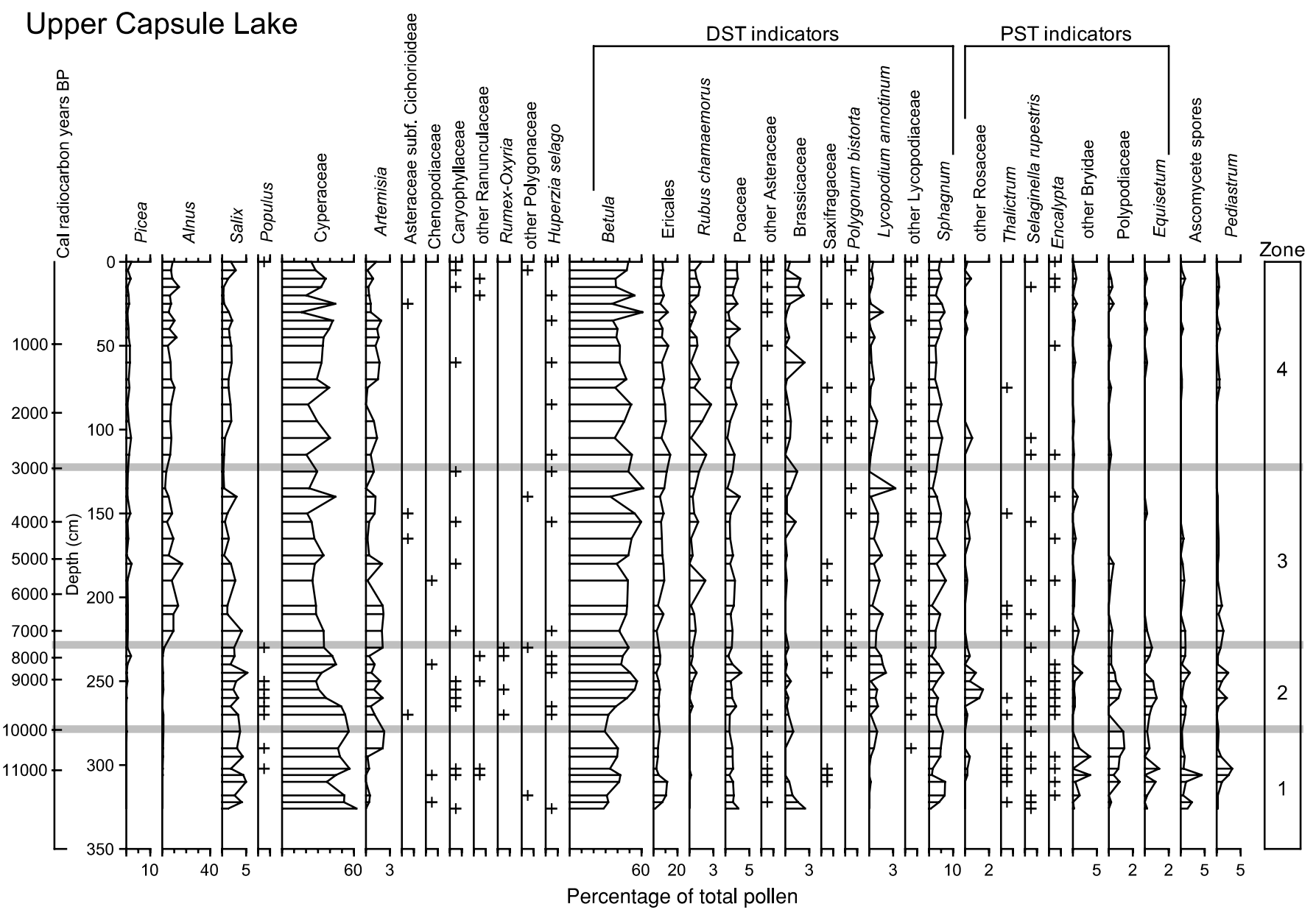

Fig. 3 Pollen and spore percentage diagram for Upper Capsule Lake (analysis by W.W. Oswald). Pollen, spores and Pediastrum are expressed as a percentage of the total pollen sum. Scales of the $x$ axes vary. Taxa are classified as indicators of DST or PST vegetation based on their patterns in modern pollen assemblages (Table 1). Symbols $(+)$ indicate $<2 \%$.

The presence of Populus pollen in UC-1 corroborates other evidence that Populus balsamifera occurred north of the Brooks Range during the early Holocene (Detterman 1970; Hopkins et al. 1981; Oswald et al. 1999).

The source of the ascomycete spores in UC-1 assemblages is uncertain. If the spores were derived from soil ascomycetes, their abundance may reflect moderate soil moisture conditions, as most tundra fungi are negatively affected by excessively wet or dry soils (e.g. Dowding \& Widden 1974). Alternatively, the spores may reflect past lichen cover, as ascomycetes are the fungal partner for the overwhelming majority of lichens (Hale 1983), and fruticose lichens are presently widespread in northern Alaska (Thomson 1979), particularly in relatively xeric tundra like PST (Evans et al. 1989; Walker et al. 1994). However, the production of spores by lichenized ascomycetes is relatively low compared with other ascomycetes (J. Ammirati, personal communication), so this explanation is less likely. In either case the presence of ascomycete spores in UC-1

(C) 2003 British Ecological Society, Journal of Ecology, 91, 1034-1048 is consistent with our characterization of the early Holocene vegetation of the Sagavanirktok surface as similar to modern PST, as this type of tundra has both moderately drained soils and high lichen cover.
EARLY TO MIDDLE HOLOCENE TRANSITION (ZONE 2: $10000-7500$ CAL YEARS BP)

In UC-2, Cyperaceae percentages decrease to $25-40 \%$, Betula percentages increase to $40-50 \%$, and minor taxa are indicative of both PST and DST. Taxa associated with modern PST are still present (Selaginella rupestris, Encalypta, Polypodiaceae and Equisetum), and percentages of Rosaceae, another PST indicator, are even higher than in UC-1. However, Bryidae percentages are lower than in UC-1 and taxa indicative of modern DST (Rubus chamaemorus, Polygonum bistorta, Lycopodium annotinum and Lycopodiaceae) are regularly encountered. The presence of both PST and DST indicators in UC-2 spectra is manifest in the multivariate analyses (Fig. 5), which indicate that the fossil assemblages are not analogous to modern vegetation of either the Itkillik II or the Sagavanirktok surface (CMD > 13). Overall, these palynological changes suggest that both PST and DST species occurred on the Sagavanirktok surface during this transitional period. PST species were probably still present in the steeper, better-drained portions of the landscape, but Betula nana and other DST species were able to establish in mesic sites. 


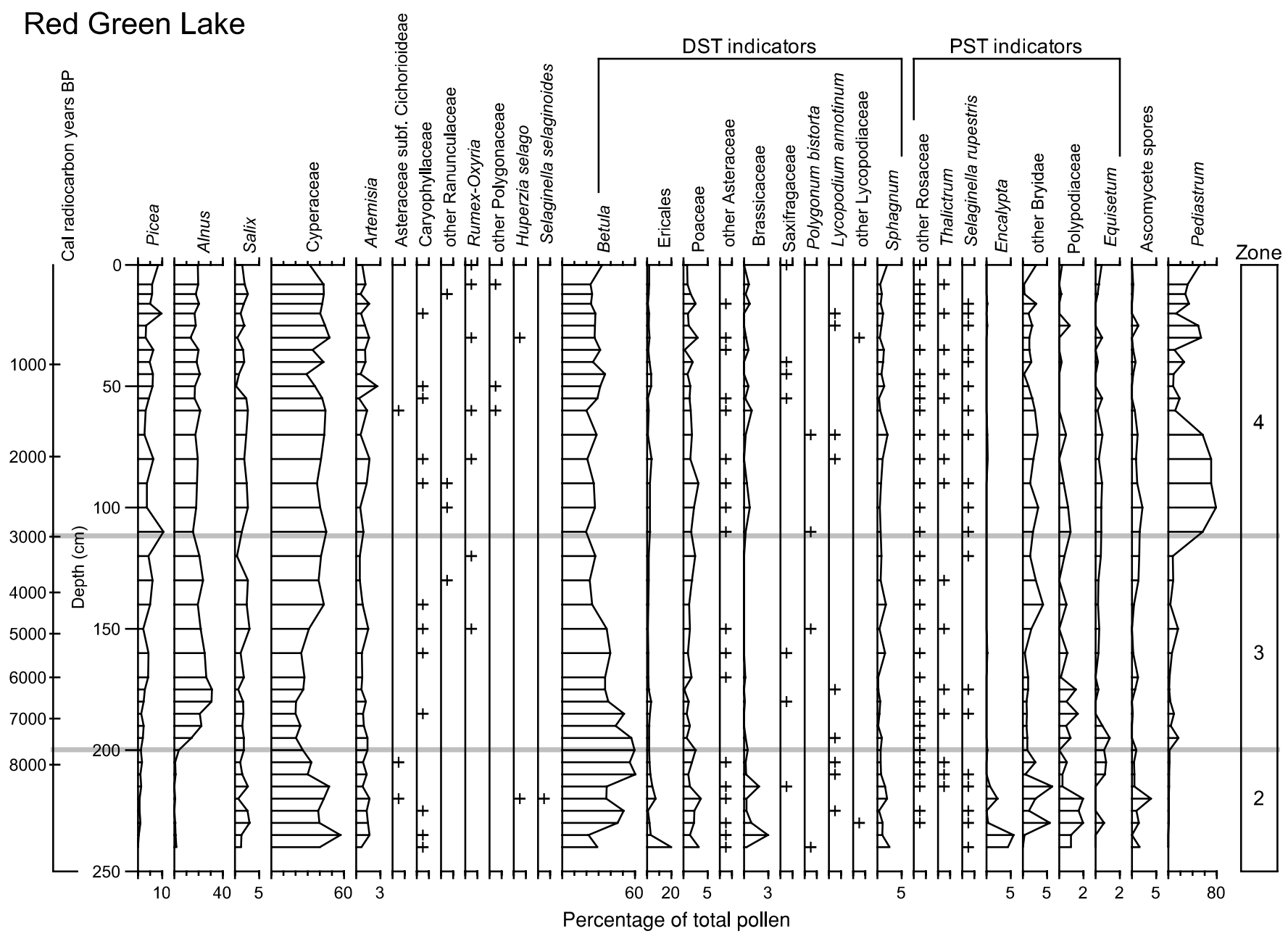

Fig. 4 Pollen and spore percentage diagram for Red Green Lake (analysis by W.W. Oswald). Pollen, spores and Pediastrum are expressed as a percentage of the total pollen sum. Scales of the $x$ axes vary. Taxa are classified as indicators of DST or PST vegetation based on their patterns in modern pollen assemblages (Table 1). Symbols $(+)$ indicate $<2 \%$.

(C) 2003 British Ecological Society, Journal of Ecology, 91, $1034-1048$
The Red Green Lake record (Fig. 4) begins at 8400 cal years BP, in the middle of zone 2 . The lake probably started to fill at this time as a result of the regional increase in effective moisture (Edwards et al. 2001). Total PARs are low $\left(<700\right.$ grains $\mathrm{cm}^{-2}$ year $\left.^{-1}\right)$ throughout RG-2, suggesting sparse overall vegetation cover (Fig. 6). Betula pollen increases from 30 to $60 \%$ and Cyperaceae percentages decrease from 60 to $25 \%$. However, the low PARs for these taxa indicate that Betula nana and Cyperaceae species were not abundant. The minor taxa (Rosaceae, Selaginella rupestris, Bryidae, Polypodiaceae and Equisetum) are indicative of PST, and ascomycete spores are also present. Comparison with the modern spectra suggests that the vegetation of RG-2 was similar to the current tundra of the Itkillik II surface (CMD < 13), especially during the upper portion of this zone. The relatively high percentages of Encalypta, Bryidae and Polypodiaceae spores in the lower portion of RG-2 indicate that the vegetation near Red Green was actually drier and more open than modern PST tundra prior to around 8000 cal years BP.
MIDDLE HOLOCENE (ZONE 3: 7500-3000 CAL YEARS BP)

At both sites, increased percentages of Picea and Alnus c. 7500 cal years BP reflect the expansion of these taxa in the regional vegetation. Records from northern Alaska show that Picea glauca and P. mariana reach their modern range limits in the southern foothills of the central Brooks Range between 8000 and 7000 cal years BP (e.g. Anderson \& Brubaker 1994). However, it is unlikely that either Picea species occurred in the Arctic Foothills during this interval, as Picea percentages in UC-3 and RG-3 do not exceed modern values. Alnus crispa occurs north of the Brooks Range (Viereck \& Little 1972), but is not currently found in the study area. Percentages of Alnus are slightly higher than modern between 7500 and 5000 cal years BP, similar to other sites in the central and western Brooks Range (e.g. Anderson \& Brubaker 1994), suggesting that Alnus species were more abundant in the regional vegetation than they are at present.

In UC-3, PST taxa decrease in abundance, DST taxa increase in abundance, and pollen assemblages become 
1042

W. Wyatt Oswald

et al.

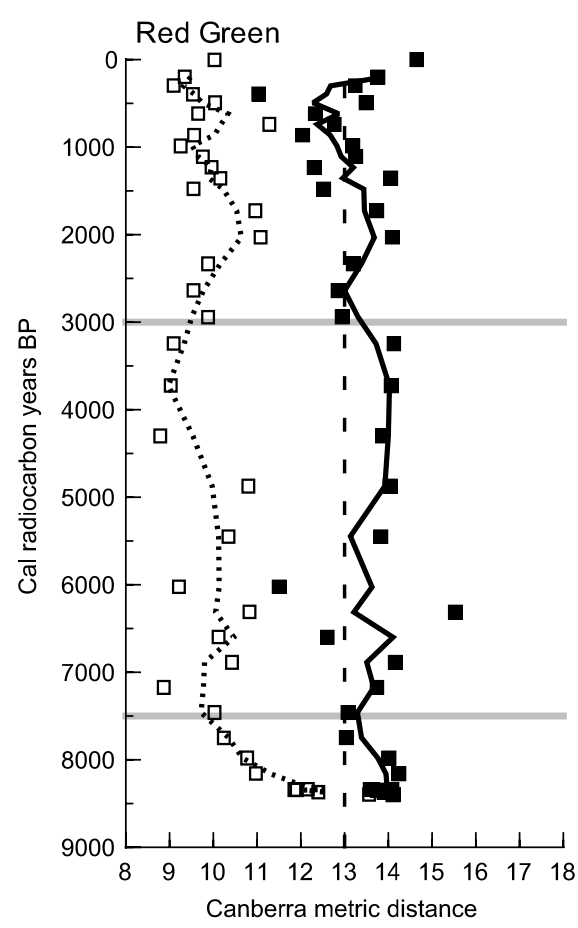

Average CM distance to Itkillik II

Average CM distance to Sagavanirktok

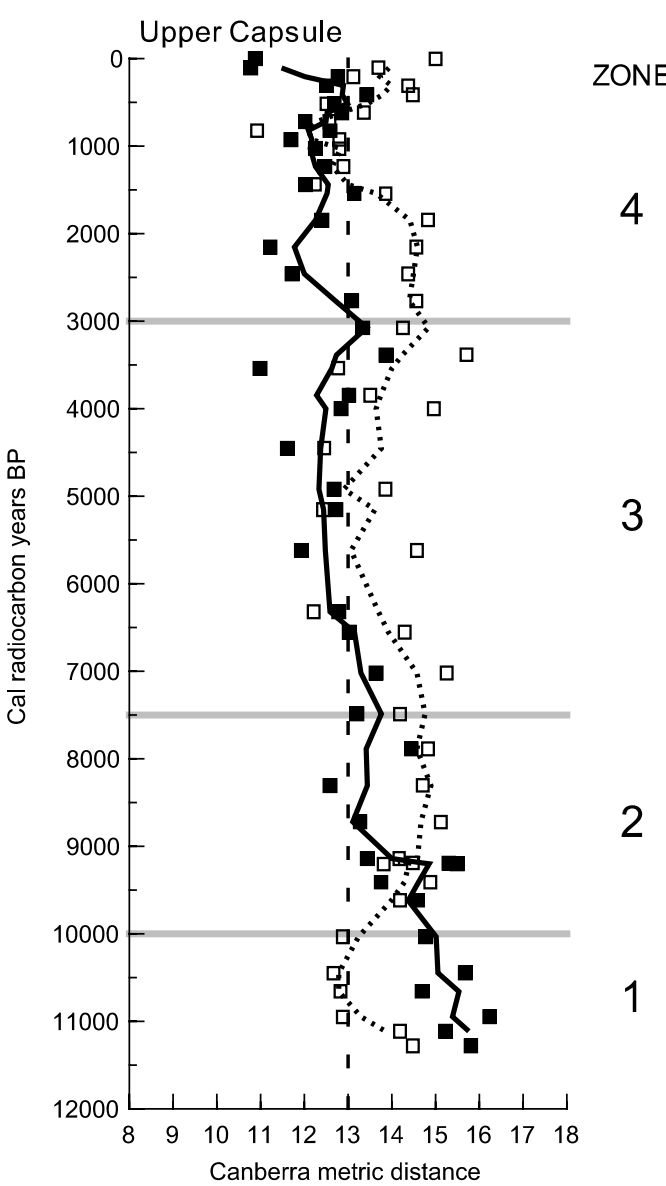

4

Fig. 5 Canberra metric distance (CMD) comparison of Red Green and Upper Capsule fossil pollen assemblages with modern pollen assemblages from the Itkillik II and Sagavanirtok surfaces. Each point is the average value of a fossil assemblage to the modern samples of either the Itkillik II or Sagavanirktok surface. Summary lines are three-point moving averages. The vertical lines show the CMD critical value separating samples from like $(\mathrm{CMD}<13)$ and unlike $(\mathrm{CMD}>13)$ vegetation types (Oswald et al. 2003b).

analogous to the modern spectra of the Sagavanirktok surface $(\mathrm{CMD}<13)$. Specifically, Salix percentages decline slightly between UC-2 and UC-3, and most PST indicators (Rosaceae, Bryidae, Polypodiaceae and Equisetum) are either absent or very rare in UC-3. On the other hand, percentages of DST indicators, including Ericales, Rubus chamaemorus, Lycopodium annotinum, Lycopodiaceae and Sphagnum, either increase or remain relatively high. These changes mark the end of the transition from PST dominance in UC-1 to the DST ecosystem that exists today in the Upper Capsule watershed. By the start of UC-3 (7500 cal years BP), Upper Capsule pollen assemblages indicate that DST had come to dominate those portions of the landscape that were occupied by PST in the preceding zone, and the increase in PARs, particularly for Betula, suggests that vegetation cover was higher overall. A coincident decrease in ascomycete spore abundance may reflect an increase in soil moisture that was unfavourable to soil ascomycetes, or perhaps reduced lichen cover on the Sagavanirktok surface. The latter interpretation is consistent with the recent finding that the abundance of lichens decreases in response to increased vascular plant biomass (Cornelissen et al. 2001).
In contrast to the substantial changes in pollen and spore percentages in the Upper Capsule record, there are only minor changes in the Red Green record between zones 2 and 3. Percentages of Brassicaceae and Equisetum decrease slightly, but overall the pollen assemblages continue to exhibit similarity to the modern vegetation of the Itkillik II surface (CMD < 13). Percentages of the major taxa vary during this zone, with Betula decreasing from 60 to $25 \%$ and Cyperaceae increasing from 20 to $40 \%$. However, as in RG-2, PARs for Betula and Cyperaceae are consistently low throughout RG-3, indicating that neither Betula nana nor Cyperaceae species were abundant.

\section{LATE HOLOCENE (ZONE 4: 3000 CAL YEARS BP TO PRESENT)}

Minor palynological changes occur between zones 3 and 4 at both sites. In the Red Green record, percentages of a number of minor taxa are higher in RG-4 than in RG-3, including both DST indicators (Ericales, Brassicaceae and Lycopodium annotinum) and PST indicators (Thalictrum and Selaginella rupestris). In the Upper Capsule record, spores of Polypodiaceae
Journal of Ecology, 91, 1034-1048 
Holocene pollen records from northern Alaska
(C) 2003 British Ecological Society, Journal of Ecology, 91, 1034-1048

Red Green
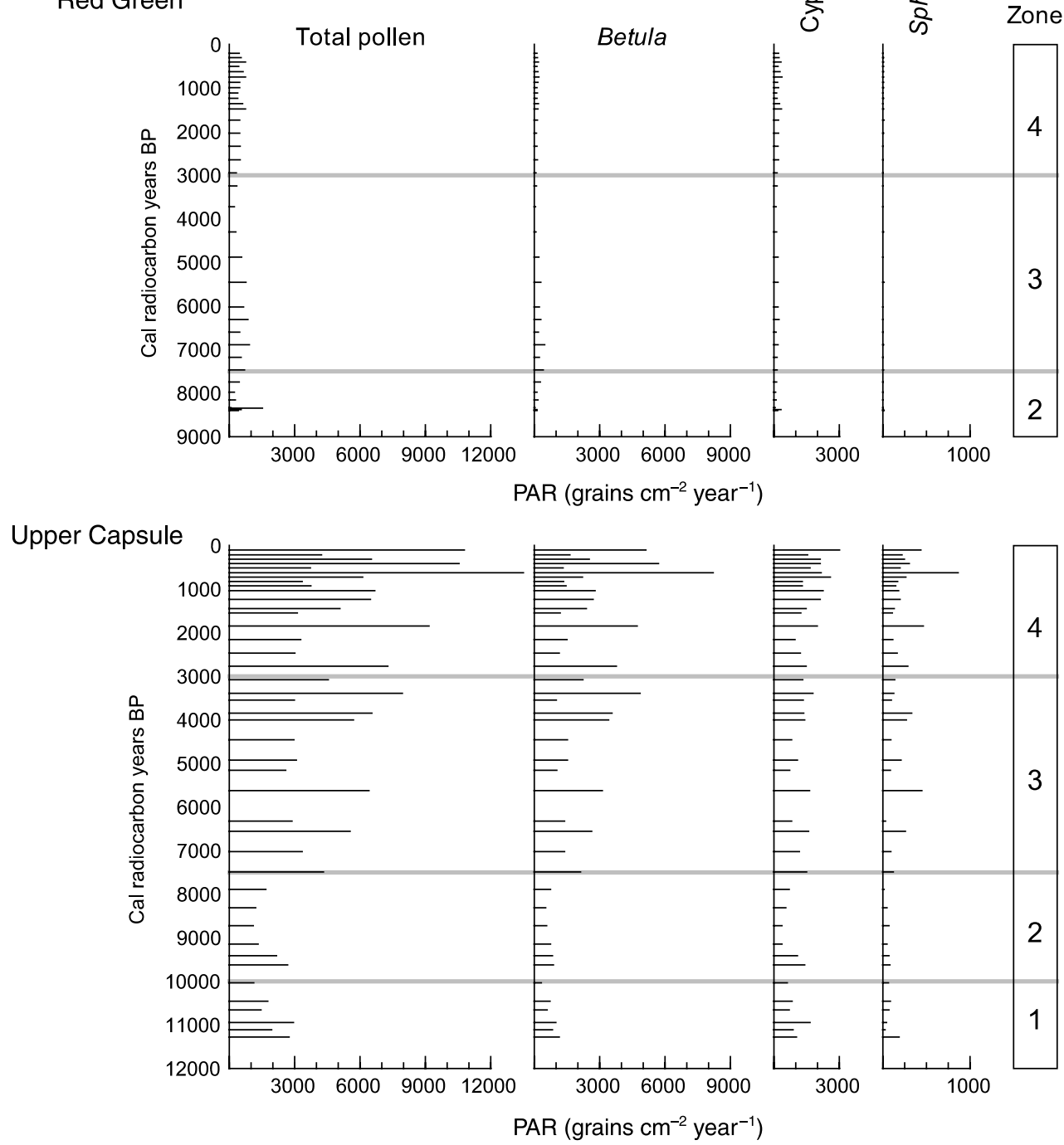

Fig. 6 Total pollen accumulation rates (PARs) and PARs for selected taxa in the pollen records from Red Green Lake (RG) and Upper Capsule Lake (UC). Five levels with artificially inflated PARs are not shown. Those levels include RG $220 \mathrm{~cm}=4319$ grains cm ${ }^{-2}$ year ${ }^{-1}, \mathrm{RG} 225 \mathrm{~cm}=21128$ grains cm${ }^{-2}$ year $^{-1}, \mathrm{RG} 230 \mathrm{~cm}=1511$ grains cm$^{-2}$ year $^{-1}, \mathrm{UC} 255 \mathrm{~cm}=54571 \mathrm{grains} \mathrm{cm}^{-2}$ year ${ }^{-1}$, and UC $260 \mathrm{~cm}=40669$ grains cm$^{-2}$ year $^{-1}$. Scale of $x$ axis for Sphagnum differs from other taxa.

and Huperzia selago are encountered more frequently in UC-4 than in UC-3, and spores of Lycopodium annotinum are slightly less common. These changes are small relative to those observed during the early and middle Holocene, and their meaning is difficult to interpret as the PST and DST taxa do not vary consistently. Nevertheless, the contemporaneous changes in the abundance of several taxa at 3000 cal years BP indicate that the vegetation of both surfaces varied to some extent between the middle and late Holocene, perhaps in response to cooler or wetter climatic conditions during this interval (e.g. Hamilton 1986). The sharp rise in the percentages of Pediastrum algal cell nets in RG-4 are also notable, although their meaning is unclear given our uncertainty about the controls on Pediastrum abundance (e.g. Anderson \& Brubaker 1986; Hu et al. 1995).
In addition, changes in pollen and Pediastrum percentages within zone 4 indicate further variations in climate and vegetation during the past two millennia. In the Red Green record, Pediastrum percentages decline between 1500 and $500 \mathrm{cal}$ years BP, and pollen assemblages from this interval exhibit increased similarity to the modern assemblages of the Sagavanirktok surface $(\mathrm{CMD}<13)$, although the palynological changes are minor. There is a more obvious change in the Upper Capsule record, as the similarity to Itkillik II modern pollen assemblages increases abruptly at 1500 cal years $\mathrm{BP}(\mathrm{CMD}<13)$. The changes in pollen percentages are subtle, but it appears that the increased similarity to Itkillik II modern vegetation results from slight decreases in the percentages of Lycopodiaceae, Sphagnum, Asteraceae and Betula. However, the Red Green and Upper Capsule fossil assemblages remain more 
1044

W. Wyatt Oswald

et al. similar to the modern assemblages of their corresponding surface during this interval, and after 500 cal years BP they become less similar to the modern assemblages of the contrasting surface. Taken together, these changes may reflect the response of both terrestrial and aquatic ecosystems to the century-scale climatic variations that occurred during the late Holocene, including the Medieval Warm Period and the Little Ice Age (e.g. Calkin 1988; Hu et al. 2001; Mann et al. 2002a). However, the chronology and sampling frequency of these records are not adequate for a more detailed examination of the environmental and ecological changes of the late Holocene.

\section{Discussion}

\section{EDAPHIC CONTROLS ON ECOSYSTEM RESPONSE TO CLIMATE CHANGE}

The differences in geomorphology and soil texture between the Itkillik II and Sagavanirktok glaciated surfaces were probably responsible for the disparate vegetational responses at Red Green and Upper Capsule to the climatic changes of the early to middle Holocene. As effective moisture increased between 10000 and 7500 cal years BP, we hypothesize that a more pronounced increase in soil moisture occurred on the Sagavanirktok surface because its fine-textured soils and flat landforms retained more water than the betterdrained substrates of the Itkillik II surface (Fig. 7). Higher soil moisture fostered an increase in plant cover on Sagavanirktok landscapes, which initiated a series of ecological and hydrological changes leading ultimately to the transition from PST to DST. Most important were the effects of the vegetation on the depth of the summer thaw layer. First, the increase in plant cover, in particular the upright, woody species, such as Betula nana and Vaccinium uliginosum, would have shaded the ground and thus reduced the amount of energy reaching the soil. Secondly, these woody, dwarfshrub species, as well as mosses, contributed slowly decomposing litter to the soil (Hobbie 1996), thus helping to create a thicker organic layer. Thirdly, the deep layer of organic litter, mosses and sedge tussocks would have further reduced thermal conductance to the soil, and together these changes would have caused a major reduction in soil temperature and reduced soil thawing (Klinger 1996; Young et al. 1997). Shallower thawing impeded soil drainage, leading to anoxic and acidic soil conditions. The combination of cold soil temperatures, increased abundance of recalcitrant litter, and especially soil anoxia and acidity, would have greatly reduced decomposition rates (Hobbie 1996; Johnson et al. 1996). In turn, even thicker organic layers contributed further to permafrost aggradation (Van Cleve et al. 1991). The outcome of this transition can be seen today, as soils of DST have thicker organic horizons (c. $20 \mathrm{~cm}$ vs. c. $10 \mathrm{~cm}$ ) and shallower active layers (thaw depth of $c .40 \mathrm{~cm}$ vs. $c .55 \mathrm{~cm}$ ) than soils of PST (Bockheim et al. 1998; Walker et al. 2001).

The pollen records from Upper Capsule and Red Green lakes shed new light on the origin of the differences between DST and PST. The importance of the ecological and hydrological feedbacks in DST has been noted
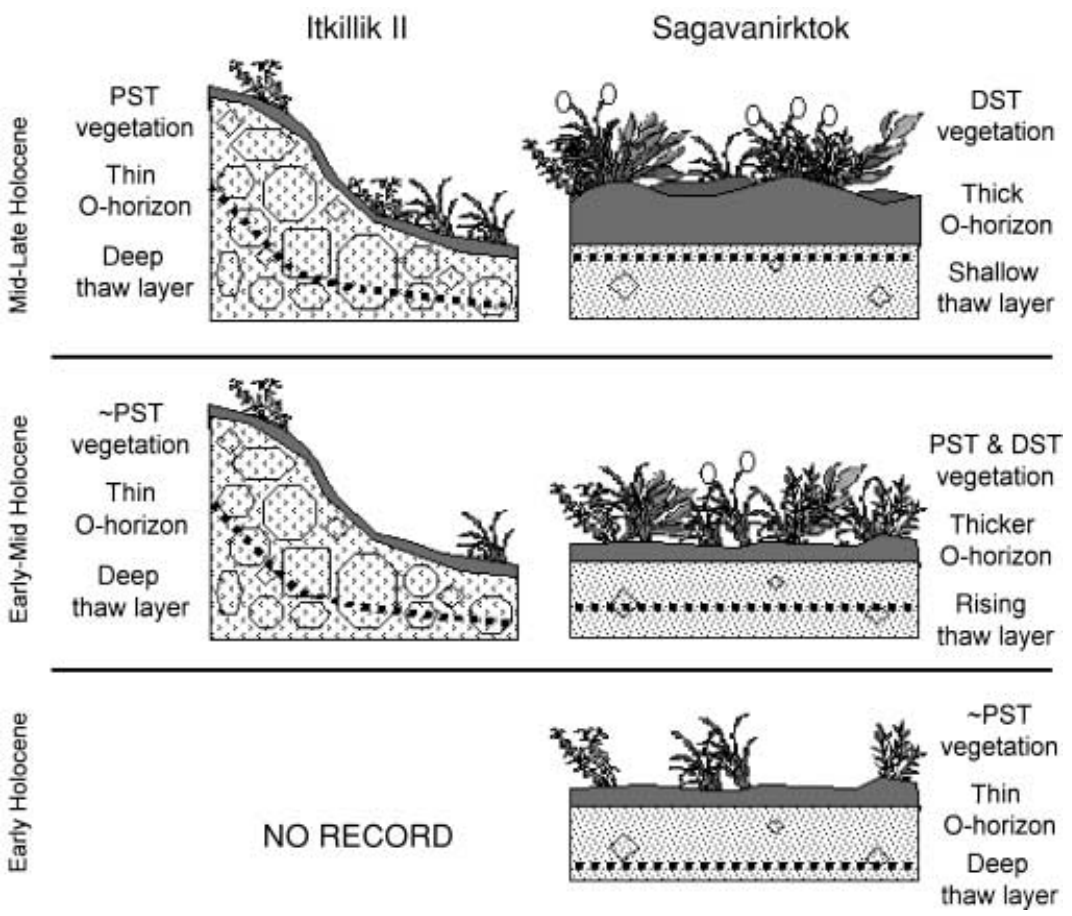

(C) 2003 British Ecological Society, Journal of Ecology, 91, 1034-1048
Fig. 7 Schematic diagram illustrating the vegetation and soil characteristics of Itkillik II and Sagavanirktok surface ecosystems before, during and after the early to middle Holocene increase in effective moisture, as inferred from the Red Green and Upper Capsule pollen records. Dashed lines indicate thaw depth. 
1045

Holocene pollen records from northern Alaska previously (e.g. Walker et al. 1989, 1994), but the manner in which these differences arose is not clearly understood. Jorgenson (1984) made the insightful observation that different tundra ecosystems occupied the Sagavanirktok and Itkillik II glaciated surfaces, leading to the hypothesis that plant community succession occurred in response to long-term landscape evolution. This hypothesis suggested that as glacial deposits in the Arctic Foothills aged over millennia, they experienced mass wasting, slope reduction, eolian deposition, the development of a thick layer of organic matter and vegetation (especially Sphagnum), and ice aggradation (Jorgenson 1984; Walker et al. 1989, 1994). As these changes proceeded, there was a gradual succession from PST to DST. Because the changes in landform and soil characteristics were viewed as the primary drivers of ecosystem change, this hypothesis emphasized the importance of landscape evolution over climate change in the development of DST ecosystems. More recently, pollen records from northern Alaska have helped to clarify our understanding of the role of climate in ecosystem change (e.g. Walker et al. 1995), and the records from Red Green and Upper Capsule illustrate even more clearly that DST does not result solely from landscape evolution. The topography and soil texture of glaciated landscapes most likely were transformed over many thousands of years, but the ecological changes associated with the switch from PST to DST occurred more rapidly. At Upper Capsule, DST developed over a relatively short interval (c. 2500 years) when cool, moist climatic conditions acted upon the smooth topography and fine-textured soils of the Sagavanirktok surface.

\section{COMPARISON WITH OTHER}

\section{PALAEOECOLOGICAL EVIDENCE}

The changes in the Red Green and Upper Capsule records are consistent with other palaeoecological records from the Arctic Foothills and elsewhere in northern Alaska, suggesting that edaphic controls on the vegetational response to Holocene climate change were important throughout the region. Nearby sites on the Sagavanirktok surface show a gradual change from PST to DST during the middle Holocene, similar to the transition at Upper Capsule. For example, at Oil Lake (2 km northwest of Upper Capsule), PST indicators (Equisetum and Polypodiaceae) have highest percentages $c$. 12 500-10 000 cal years BP, slightly lower percentages during the transition from 10000 to 7500 cal years BP, and are nearly absent after 7500 cal years BP. On the other hand, DST indicators (Lycopodium annotinum and Ericales) are present in low percentages during the transitional period, but become more abundant (including Rubus chamaemorus and Polygonum bistorta) after $7500 \mathrm{cal}$ years BP (Eisner \& Colinvaux 1992; W. Oswald and L. Brubaker, unpublished data). Pollen records from a peat deposit at Imnavait Creek (10 km east of Upper Capsule) and Ahaliorak Lake (60 km north-west of the study area, Anaktuvuk surface) lack the temporal resolution to perceive the details of this transition, but in general their stratigraphy is consistent with the Upper Capsule record. The Imnavait Creek record has relatively high percentages of PST indicators (Equisetum and Rosaceae) during the early Holocene (Eisner 1991), whereas the Ahaliorak record has higher percentages of Ericales pollen in the late Holocene than in the early Holocene (Eisner \& Colinvaux 1990; P. Anderson and L. Brubaker, unpublished data).

Similar palynological changes are evident at sites in the western Brooks Range and Arctic Foothills that, like Upper Capsule, were not glaciated during the late Pleistocene. In pollen records from the Kobuk and Noatak drainages, percentages of Polypodiaceae and Equisetum are generally high during the early Holocene, and a transition occurs between the early and middle Holocene to assemblages featuring higher percentages of Ericales, Sphagnum and Lycopodium (Anderson 1985, 1988; Anderson et al. 1994). These sites differ from Red Green and Upper Capsule in that they have higher percentages of Betula, Alnus and Sphagnum and lower percentages of Cyperaceae during the Holocene. The pollen record from Tukuto Lake in the western Arctic Foothills shares many of the same stratigraphic patterns as the Upper Capsule record, including an interval when both PST and DST indicator taxa are present. During the beginning of the Holocene, Tukuto assemblages have relatively high percentages of Polypodiaceae and Equisetum spores. That zone is followed by the transitional period in which the PST indicators are present at low percentages and DST indicators (Ericales and Rubus chamaemorus) also occur. Lastly, there is a switch to DST c. 7500 cal years BP indicated by the near absence of PST taxa and increased percentages of Ericales (Oswald et al. 1999). A notable difference between this record and that of Upper Capsule is that Lycopodium annotinum percentages decrease after 7500 cal years BP at Tukuto but not at Upper Capsule. The pollen record from Lake of the Pleistocene, a late glacial to early Holocene deposit located near Tukuto Lake, shares some similarities with the Upper Capsule record, including the first occurrence of Rubus chamaemorus pollen c. 9500 cal years BP (Mann et al. 2002b). In addition, the record from Red Green Lake is similar to two pollen records from recently glaciated sites in the western Brooks Range. Etivlik Lake (Itkillik II surface) and Feniak Lake (Itkillik I surface) have relatively high percentages of Equisetum and Polypodiaceae spores in the early Holocene, but do not exhibit the change to DST in the middle Holocene that characterizes records from older glaciated surfaces (Eisner \& Colinvaux 1992; Oswald et al. 1999).

The consistent patterns of indicator taxa in these records suggests that the early to middle Holocene changes in vegetation observed in the central Arctic Foothills occurred regionally, but with some variability related to geographical and edaphic factors. In both the central Arctic Foothills and the western Brooks Range, tundra apparently similar to modern PST was present
Ecological Society, Journal of Ecology, 91, 1034-1048 
1046

W. Wyatt Oswald

et al.

at the beginning of the Holocene. However, between $c$. 10000 and 7500 cal years BP there was a transition from PST to DST on Sagavanirktok and other old surfaces, after which PST taxa were no longer abundant in the vegetation. In contrast, the pollen records from Red Green Lake and other sites on recently glaciated surfaces (Etivlik Lake and Feniak Lake) show that areas with coarse-textured substrates did not undergo this vegetational change. Instead, these surfaces have been occupied by tundra not unlike modern PST since at least $8500 \mathrm{cal}$ years BP.

Related evidence for past tundra ecosystem dynamics in northern Alaska comes from ${ }^{14} \mathrm{C}$ dates on basal organic deposits, which have been interpreted as representing the onset of paludification and organic peat accumulation (Mann et al. 2002b). A recent analysis of basal organic dates from relatively old surfaces (> $14000{ }^{14} \mathrm{C}$ years $\mathrm{BP}$ ) across this region suggests that peat accumulation began $c .15000$ cal years BP in topographic low points, and by c. 9500 cal years BP occurred on most areas of the landscape (Mann et al. 2002b). The palynological evidence from Upper Capsule Lake and other sites on older glaciated surfaces is generally consistent with this interpretation of the history of paludification, although the pollen records suggest that organic soils did not achieve their current coverage until a somewhat later date. For example, Sphagnum spores were encountered throughout the Upper Capsule record and after $12800{ }^{14} \mathrm{C}$ years BP in the Tukuto Lake record (Oswald et al. 1999), indicating that some mesic substrates have been present in those watersheds since the late glacial interval. Likewise, the pattern of DST indicator taxa in the Upper Capsule record suggests that Sagavanirktok surface soils became wetter and more acidic beginning at 10000 cal years BP. However, the stratigraphic pattern of taxa associated with PST indicates that some relatively xeric substrates were present until c. $7500 \mathrm{cal}$ years BP, which is 2000 years later than the basal organic dates would suggest.

\section{IMPLICATIONS}

The finding that Sagavanirktok and other old surface ecosystems experienced a stronger vegetational response to Holocene climatic change than their recently glaciated counterparts suggests that old, weathered landscapes may be more susceptible to major environmental changes in the future. If, as in the early Holocene, future warming results in lower effective moisture in northern Alaska, we might expect the complex feedbacks of the DST ecosystems to be disrupted. For example, warmer conditions might reduce soil moisture and accelerate soil decomposition rates (e.g. Hobbie 1996), reducing vegetation cover and the depth

(C) 2003 British Ecological Society, Journal of Ecology, 91, 1034-1048 of the organic layer, and thus leading to deeper permafrost thawing and even drier soils. In contrast, the vegetation of Itkillik II surface was relatively insensitive to past climate change, and therefore may not be as strongly affected by future warming as the Sagavanirktok surface. Because their coarse-texture results in inherently low water-holding capacity, Itkillik II soils are likely to support relatively xeric, sparse tundra vegetation regardless of climate. The effect of substrate on ecosystem sensitivity to climate change may also be important at the circumarctic scale. Substrate varies greatly across the Arctic, with heterogeneity occurring at a variety of spatial scales, and resulting from many different factors (e.g. glacial history, parent material or eolian deposition; Walker et al. 1998; Walker 2000). The critical role of substrate in the Holocene ecosystem history of the central Arctic Foothills suggests that this edaphic variability may impart strong spatial heterogeneity on how arctic tundra ecosystems respond to future climate change.

\section{Acknowledgements}

We acknowledge the Toolik Field Station and the BLM Northern Field Office for logistical support and assistance with research permits, respectively. We thank Torre and Janet Jorgenson for loaning field equipment, Terry Chapin for help with site selection, Dan Gavin, Jeremiah Knuth, Gary Michaelson and Chien-Lu Ping for field assistance, Patricia Gomez for laboratory help, and Joe Ammirati, Tom Brown, Mary Edwards, Wendy Fujikawa, Laura Gough, Phil Higuera, Kristina Hill, Sarah Hobbie, Marilyn Walker and Skip Walker for their contributions. We are grateful to Pat Anderson, Shelley Crausbay, Charlie Halpern, Doug Sprugel, Darlene Zabowski, Lindsay Haddon and two anonymous referees for their careful reviews of the manuscript. This research was funded by National Science Foundation grant OPP-9615947. This is contribution 207 from the Palaeoenvironmental Arctic Science (PARCS) programme.

\section{References}

Abbott, M.B., Finney, B.P., Edwards, M.E. \& Kelts, K.R. (2000) Paleohydrology of Birch Lake, central Alaska: lakelevel reconstructions using seismic reflection profiles and core transect approaches. Quaternary Research, 53, 154-166.

Anderson, P.M. (1985) Late Quaternary vegetational change in the Kotzebue Sound area, northwestern Alaska. Quaternary Research, 24, 307-321.

Anderson, P.M. (1988) Late Quaternary pollen records from the Kobuk and Noatak River drainages, northwestern Alaska. Quaternary Research, 29, 263-276.

Anderson, L., Abbott, M.B. \& Finney, B.P. (2001) Holocene climate inferred from oxygen isotope ratios in lake sediments, central Brooks Range, Alaska. Quaternary Research, 55, 313-321.

Anderson, P.M., Bartlein, P.M. \& Brubaker, L.B. (1994) LateQuaternary history of tundra vegetation in northwestern Alaska. Quaternary Research, 41, 306-315.

Anderson, P.M. \& Brubaker, L.B. (1986) Modern pollen assemblages from northern Alaska. Review of Palaeobotany and Palynology, 46, 273-291.

Anderson, P.M. \& Brubaker, L.B. (1994) Vegetation history of northcentral Alaska: a mapped summary of lateQuaternary pollen data. Quaternary Science Reviews, 13, $71-92$. 
1047

Holocene pollen records from northern Alaska
Bartlein, P.J., Anderson, P.M., Edwards, M.E. \& McDowell, P.F. (1992) A framework for interpreting paleoclimatic variations in eastern Beringia. Quaternary International, 10-12, 73-83.

Bartlein, P.J., Edwards, M.E., Shafer, S.L. \& Barker, E.D. Jr (1995) Calibration of radiocarbon dates and the interpretation of paleoenvironmental records. Quaternary Research, 44, 417-424.

Bockheim, J.G., Walker, D.A., Everett, L.R., Nelson, F.E. \& Shiklomanov, N.I. (1998) Soils and cryoturbation in moist nonacidic and acidic tundra in the Kuparuk River Basin, arctic Alaska, U.S.A. Arctic and Alpine Research, 30, 166-174.

Brubaker, L.B., Anderson, P.M. \& Hu, F.S. (2001) Vegetation ecotone dynamics in Southwest Alaska during the Late Quaternary. Quaternary Science Reviews, 20, 175-188.

Brubaker, L.B., Anderson, P.M., Murray, B. \& Koon, D. (1998) A palynological investigation of true moss (Bryidae) spores: morphology and occurrence in modern and LateQuaternary lake sediments of Alaska. Canadian Journal of Botany, 76, 2145-2157.

Calkin, P.E. (1988) Holocene glaciation of Alaska (and adjoining Yukon Territory, Canada). Quaternary Science Reviews, 7, 159-184.

Chapin, F.S. III, Shaver, G.S., Giblin, A.E., Nadelhoffer, K.J. \& Laundre, J.M. (1995) Responses of arctic tundra to experimental and observed changes in climate. Ecology, 76, 694-711.

Cornelissen, J.H.C., Callaghan, T.V., Alatalo, J.M., Michelsen, A., Graglia, E., Hartley, A.E. et al. (2001) Global change and arctic ecosystems: is lichen decline a function of increases in vascular plant biomass? Journal of Ecology, 89, 984-994.

Cwynar, L.C. (1982) A late Quaternary vegetation history from Hanging Lake, northern Yukon. Ecological Monographs, 52, 1-24.

Cwynar, L.C., Burden, E. \& McAndrews, J.H. (1979) An inexpensive sieving method for concentrating pollen and spores from fine-grained sediments. Canadian Journal of Earth Sciences, 16, 1115-1120.

Detterman, R.L. (1970) Early Holocene warm interval in northern Alaska. Arctic, 23, 130-131.

Dowding, P. \& Widden, P. (1974) Some relationships between fungi and their environment in tundra regions. Soil Organisms and Decomposition in Tundra (eds A.J. Holding, O.W. Heal, S.F. Maclean, Jr \& P.W. Fanagan), pp. 123-150. IBP Tundra Biome Steering Committee, Stockholm.

Edwards, M.E. \& Dunwiddie, P.W. (1985) Dendrochronological and palynological observations on Populus balsamifera in northern Alaska, U.S.A. Arctic and Alpine Research, 17, 271-278.

Edwards, M.E., Mock, C.J., Finney, B.P., Barber, V.A. \& Bartlein, P.J. (2001) Potential analogs for paleoclimatic variations in eastern interior Alaska during the past 14000 yr: atmospheric-circulation controls of regional temperature and moisture responses. Quaternary Science Reviews, 20, 189-202.

Eisner, W.R. (1991) Palynological analysis of a peat core from Imnavait Creek, the North Slope, Alaska. Arctic, 44, 279-282.

Eisner, W.R. \& Colinvaux, P.A. (1990) A long pollen record from Ahaliorak Lake, Arctic Alaska. Review of Palaeobotany and Palynology, 63, 35-52.

Eisner, W.R. \& Colinvaux, P.A. (1992) Late Quaternary pollen records from Oil Lake and Feniak Lake, Alaska, USA. Arctic and Alpine Research, 24, 56-63.

Ellis, J.M. \& Calkin, P.E. (1979) Nature and distribution of glaciers, neoglacial moraines, and rock glaciers, eastcentral Brooks Range, Alaska. Arctic and Alpine Research, 11, 403-420.

Ecological Society, Journal of Ecology, 91, 1034-1048
Elvebakk, A. (1994) A survey of plant associations and alliances from Svalbard. Journal of Vegetation Science, $\mathbf{5}$, 791-802.

Evans, B.M., Walker, D.A., Benson, C.S., Nordstrand, E.A. \& Petersen, G.W. (1989) Spatial interrelationships between terrain, snow distribution and vegetation patterns at an arctic foothills site in Alaska. Holarctic Ecology, 12, 270-278.

van Geel, B. (1972) Palynology of a section from the raised peat bog 'Wietmarscher Moor', with special reference to fungal remains. Acta Botanica Neerlandica, 21, 261-284.

van Geel, B. (1978) A paleoecologial study of Holocene peat bog sections in Germany and The Netherlands, based on the analysis of pollen, spores, and macro- and microscopic remains of fungi, algae, cormophytes, and animals. Review of Palaeobotany and Palynology, 25, 1-120.

van Geel, B., Hallewas, D.P. \& Pals, J.P. (1982) A late Holocene deposit under the Westfriese Zeedijk near Enkhuizen (Prov. of Noord-Holland, The Netherlands): paleoecological and archaeological aspects. Review of Palaeobotany and Palynology, 38, 269-335.

Gough, L., Shaver, G.R., Carroll, J., Royer, D.L. \& Laundre, J.A. (2000) Vascular plant species richness in Alaskan arctic tundra: the importance of pH. Journal of Ecology, 88, 54 66.

Guthrie, R.D. (1985) Woolly arguments against the mammoth steppe- a new look at the palynological data. Quarterly Review of Archaeology, 6, 9-16.

Hale, M.E. Jr (1983) The Biology of Lichens, 3rd edn. Edward Arnold, London.

Hamilton, T.D. (1978) Surficial Geologic Map of the Philip Smith Quadrangle, Alaska. Miscellaneous Field Studies Map MF-879-A. U.S. Geological Survey, Reston.

Hamilton, T.D. (1986) Late Cenozoic glaciation of the central Brooks Range. Glaciation in Alaska: the Geologic Record (eds T.D. Hamilton, K.M. Reed \& R.M. Thorson), pp. 9 49. Alaska Geological Society, Anchorage.

Hamilton, T.D. (1994) Late Cenozoic glaciation of Alaska. The Geology of Alaska (eds G. Plafker \& H.C. Berg), pp. 813-844. Geological Society of America, Boulder.

Hobbie, S. (1996) Temperature and plant species control over litter decomposition in Alaskan tundra. Ecological Monographs, 66, 503-522.

Hopkins, D.M., Smith, P.A. \& Matthews, J.V. Jr (1981) Dated wood from Alaska and the Yukon: implications for forest refugia in Beringia. Quaternary Research, 15, 217-249.

Hu, F.S., Brubaker, L.B. \& Anderson, P.M. (1995) Postglacial vegetation and climate change in the northern Bristol Bay region, southwestern Alaska. Quaternary Research, 43, 382-392.

Hu, F.S., Ito, E., Brown, T.A., Curry, B.B. \& Engstrom, D.R. (2001) Pronounced climatic variations in Alaska during the last two millennia. Proceedings of the National Academy of Sciences, 98, 10552-10556.

Hu, F.S., Ito, E., Brubaker, L.B. \& Anderson, P.M. (1998) Ostracode geochemical record for Holocene climatic change and implications for vegetational response in the northwestern Alaska Range. Quaternary Research, 49, 8695.

Johnson, L.C., Shaver, G.R., Giblin, A.E., Nadelhoffer, K.J., Rastetter, E.R., Laundre, J.A. et al. (1996) Effects of drainage and temperature on carbon balance of tussock tundra. Oecologia, 108, 737-748.

Jorgenson, M.T. (1984) The response of vegetation to landscape evolution on glacial till near Toolik Lake, Alaska. Inventorying Forest and Other Vegetation of the High Altitude and High Latitude Regions (eds V.J. Laban \& C.L. Kerr), pp. 134-141. Society of American Foresters Regional Technical Conference, Fairbanks.

Klinger, L.F. (1996) Coupling of soils and vegetation in peatland succession. Arctic and Alpine Research, 28, 380 387. 
1048

W. Wyatt Oswald

et al.
Mann, D.H., Heiser, P.A. \& Finney, B.P. (2002a) Holocene history of the Great Kobuk Sand Dunes, Northwestern Alaska. Quaternary Science Reviews, 21, 709-731.

Mann, D.H., Peteet, D.M., Reanier, R.E. \& Kunz, M.L. (2002b) Responses of an arctic landscape to Lateglacial and early Holocene climatic changes: the importance of moisture. Quaternary Science Reviews, 21, 997-1021.

Mason, O.K. \& Jordan, J.W. (1993) Heightened North Pacific storminess during synchronous late Holocene erosion of northwest Alaska beach ridges. Quaternary Research, 40, 55-69.

McGuire, A.D., Clein, J.S., Melillo, J.M., Kicklighter, D.W., Meier, R.A., Vorosmarty, C.J. et al. (2000) Modelling carbon responses of tundra ecosystems to historical and projected climate: sensitivity of pan-Arctic carbon storage to temporal and spatial variation in climate. Global Change Biology, 6, 141-159.

Morison, J., Aagaard, K. \& Steele, M. (2000) Recent environmental change in the Arctic: a review. Arctic, 53, 359-371.

Muller, S.V., Racoviteanu, A.E. \& Walker, D.A. (1999) Landsat MSS-derived land-cover map of northern Alaska: extrapolation methods and a comparison with photointerpreted and AVHRR-derived maps. International Journal of Remote Sensing, 20, 2921-2946.

Munroe, J.S. \& Bockheim, J.G. (2001) Soil development in low-arctic tundra of the northern Brooks Range, Alaska, U.S.A. Arctic, Antarctic, and Alpine Research, 33, 78-87.

Nelson, R.E. \& Carter, L.D. (1987) Paleoenvironmental analysis of insects and extralimital Populus from an early Holocene site on the Arctic Slope of Alaska. Arctic and Alpine Research, 19, 230-241.

Oechel, W.C., Vourlitis, G.L., Hastings, S.J., Zulueta, R.C., Hinzman, L. \& Kane, D. (2000) Acclimation of ecosystem $\mathrm{CO}_{2}$ exchange in the Alaskan Arctic in response to decadal climate warming. Nature, 406, 978-981.

Oswald, W.W. (2002) Holocene vegetational history of the central Arctic Foothills, northern Alaska: pollen representation of tundra and edaphic controls on the response of tundra to climate change. PhD dissertation. University of Washington, Seattle.

Oswald, W.W., Anderson, P.M., Brubaker, L.B., Hu, F.S. \& Engstrom, D.R. (2003a) Representation of tundra vegetation by pollen in lake sediments of northern Alaska. Journal of Biogeography, 30, 521-535.

Oswald, W.W., Brubaker, L.B. \& Anderson, P.M. (1999) Late Quaternary vegetational history of the Howard Pass area, northwestern Alaska. Canadian Journal of Botany, 77, 570 581.

Oswald, W.W., Brubaker, L.B., Hu, F.S. \& Gavin, D.G. (2003b) Pollen-vegetation calibration for tundra communities in the Arctic Foothills, northern Alaska. Journal of Ecology 91, 1022-1033.

Overpeck, J.T., Webb, T. III \& Prentice, I.C. (1985) Quantitative interpretation of fossil pollen spectra: dissimilarity coefficients and the method of modern analogs. Quaternary Research, 23, 87-108.

Serreze, M.C., Walsh, J.E., Chapin, F.S., Osterkamp, T., Dyurgerov, M., Romanovsky, V. et al. (2000) Observational evidence of recent change in the northern high-latitude environment. Climatic Change, 46, 159-207.
Stockmarr, J. (1971) Tablets with spores used in absolute pollen analysis. Pollen et Spores, 13, 615-621.

Stuiver, M. \& Reimer, P.J. (1993) Extended ${ }^{14} \mathrm{C}$ database and revised CALIB radiocarbon calibration program. Radiocarbon, 35, 215-230.

Sturm, M., Racine, C. \& Tape, K. (2001) Increasing shrub abundance in the Arctic. Nature, 411, 546-547.

Thomson, J.W. (1979) Lichens of the Alaskan Arctic Slope. University of Toronto Press, Toronto.

Van Cleve, K., Chapin, F.S. III, Dyrness, C.T. \& Viereck, L.A. (1991) Element cycling in taiga forests: state-factor control. Bioscience, 41, 78-88.

Viereck, L.A. \& Little, E.L. Jr (1972) Alaska Trees and Shrubs. U.S. Department of Agriculture, Washington.

Walker, D.A. (1999) An integrated vegetation mapping approach for northern Alaska (1:4 M scale). International Journal of Remote Sensing, 20, 2895-2920.

Walker, D.A. (2000) Hierarchical subdivision of Arctic tundra based on vegetation response to climate, parent material and topography. Global Change Biology, 6, 19-34.

Walker, D.A., Auerbach, N.A., Bockheim, J.G., Chapin, F.S. III, Eugster, W., King, J.Y. et al. (1998) Energy and tracegas fluxes across a soil pH boundary in the Arctic. Nature, 394, 469-472.

Walker, D.A., Auerbach, N.A. \& Shippert, M.M. (1995) NDVI, biomass, and landscape evolution of glaciated terrain in northern Alaska. Polar Record, 31, 169-178.

Walker, D.A., Binnian, E., Evans, B.M., Lederer, N.D., Nordstrand, E. \& Webber, P.J. (1989) Terrain, vegetation and landscape evolution of the R4D research site, Brooks Range Foothills, Alaska. Holarctic Ecology, 12, 238-261.

Walker, D.A., Bockheim, J.G., Chapin, F.S., Eugster, W., Nelson, F.E. \& Ping, C.L. (2001) Calcium-rich tundra, wildlife, and the 'Mammoth Steppe'. Quaternary Science Reviews, 20, 149-163.

Walker, D.A. \& Everett, K.R. (1991) Loess ecosystems of northern Alaska: regional gradient and toposequence at Prudhoe Bay. Ecological Monographs, 61, 437-464.

Walker, M.D., Walker, D.A. \& Auerbach, A.N. (1994) Plant communities of a tussock tundra landscape in the Brooks Range Foothills, Alaska. Journal of Vegetation Science, $\mathbf{5}$, 843-866.

Wright, H.E. Jr, Mann, D.H. \& Glaser, P.H. (1984) Piston corers for peat and lake sediments. Ecology, 65, 657-659.

Young, S.B. (1971) The vascular flora of St. Lawrence Island with special reference to floristic zonation in the arctic regions. Contributions from the Gray Herbarium, 201, 11115.

Young, K.L., Woo, M.K. \& Edlund, S.A. (1997) Influence of local topography, soils, and vegetation on microclimate and hydrology at a high Arctic site, Ellesmere Island, Canada. Arctic and Alpine Research, 29, 270-284.

Yurtsev, B.A. (1994) Floristic division of the Arctic. Journal of Vegetation Science, 5, 765-776.

Zhang, T., Osterkamp, T.E. \& Stamnes, K. (1996) Some characteristics of climate in northern Alaska, U.S.A. Arctic and Alpine Research, 28, 509-518.

Received 23 December 2002

revision accepted 22 July 2003 